\title{
EFEKTIVITAS PENGGUNAAN MODEL PEMBELAJARAN MAHARAH KALAM BERBASIS TEORI KONSTRUKTIVESME DALAM MENINGKATKAN MOTIVASI BELAJAR SISWA
}

\author{
M. Dzikrul Hakim Al Ghozali*1, \\ 1Pendidikan Bahasa Arab \\ Universitas KH. Abdul Wahab Hasbullah Jombang \\ Email : adzik202@gmail.com \\ Diki Cahyo Ramadhan ${ }^{2}$ \\ 2Pendidikan Bahasa Arab \\ Universitas KH. Abdul Wahab Hasbullah Jombang \\ Email : dikicahyo@gmail.com,
}

\begin{abstract}
The purpose of this research is to find out how effective the use of the constructivist theorybased maharah kalam learning model is on the learning motivation of the students of Madrasah Aliyah Al-Bairuny Sambong, Jombang hamlet. The type of this research is experimental research with One Group pretest-posttest model using a quantitative approach. The sampling method uses the Porpusive Sampling technique. For data collection techniques used test techniques and non-test techniques. The test technique uses Pretest-Posttest multiple choice questions as an instrument. The non-test technique uses a questionnaire questionnaire. The results showed that the use of the constructivism theory-based speaking skills learning model could improve student learning outcomes and motivation.
\end{abstract}

Keywords: Constructivism Theory, Learning Speaking Skills, Learning Motivation.

\begin{abstract}
Abstrak
Tujuan penelitian untuk mengetahui bagaimana efektifitas penggunaan model pembelajaran maharah kalam berbasis teori konstruktivsme terhadap motivasi belajar siswa Madrasah Aliyah Al-Bairuny Sambong dukuh Jombang. Adapun jenis penelitian ini adalah penelitian eksperimen dengan model One Group pretes-posttest dengan menggunakan pendekatan kuantitatif. Metode pengambilan sampel menggunakan teknik Porpusive Sampling. Untuk teknik pengumpulan data digunakan teknik test dan teknik non test. Teknik test menggunakan Pretest-Postest
\end{abstract}




\section{Dzikrul Hakim Al Ghozali, Diki Cahyo Ramadhan.}

soal multiple choice sebagai instrumen. Teknik non-test menggunakan angket kuesioner. Hasil penelitian memperlihatkan bahwa dengan penggunaan model pembelajaran keterampilan berbicara berbasis teori konstruktivisme bisa meningkatkan hasil belajar dan motivasi belajar siswa.

Kata kunci: Teori Konstruktivisme, Pembelajaran Keterampilan Berbicara, Motivasi Belajar.

\section{A. PENDAHULUAN}

Bahasa Arab bukan hanya sekedar bahasa Agama Islam, karena kitab suci Al-Qur'an diturunkan dengan berbahasa Arab tetapi juga bahasa dunia internasional yang dipakai masyarakat global dalam berbagai bidang sosial, politik, ekonomi, dan budaya. Hal ini menunjukan bahwa bahasa Arab penting untuk dikuasai, seperti bahasa inggris dan bahasa lainya. Tujuan utama pembelajaran bahasa Asing adalah sebagai pengembangan kemampuan pelajar dalam menggunakan bahasa itu baik secara lisan maupun tulisan. Kemampuan dalam menggunakan bahasa dalam dunia pengajaran bahasa disebut keterampilan bahasa (Maharah Al-Lugah). Keterampilan tersebut ada empat, yaitu keterampilan menyimak (Maharah Al-Istima'), berbicara (Maharah Al-Kalam), membaca (Maharah Al-Qira'ah), dan Menulis (Maharah Al-Kitabah). ${ }^{1}$

Secara umum pembelajaraan bahasa Arab di Indonesia disemua jenis dan jenjang pendidikan belum berhasil seperti apa yang diharapkan. Indikator hal tersebut dapat dilihat dari minat dan kemampuan sebagian besar siswa atau pelajar yang masih rendah, jika dibandingkan dengan minat dan kemampuan

\footnotetext{
${ }^{1}$ Acep Hermawan, Metodologi Pembelajaran Bahasa Arab (Bandung : Rosdakarya, 2011), 129
} 
mereka dalam menguasai bahasa Asing lainya, khususnya bahasa Inggris. Pembelajaran bahasa Arab di sekolah, baik negri maupun swasta, adalah wajib. Secara akademis, kebijakan ini memberi peluang yang sangat besar bagi pengembangan bahasa Arab di Indonesia. Namun demikian, besarnya peluang pengembangan bahasa Arab ini, tidak berbanding lurus dengan keberhasilan bahasa Arab itu sendiri. Tidak sedikit siswa yang telah menyelesaikan studinya tetapi belum bisa sama sekali untuk berkomunikasi dengan menggunakan bahasa Arab secara baik dan benar.

Diakui banyak faktor yang melatar belakangi problema tersebut; ketersedian sarana dan prasarana yang kurang memadai, lingkungan bahasa yang belum terkondisikan, minat belajar siswa yang rendah, anggapan bahwa bahasa Arab tidak penting, dan lain-lain. Dalam kontek pembelajaran di Madrasah Aliyah, secara psikis, siswa telah sampai kepada kematangan untuk berfikir secara mandiri, mereka telah memiliki pengalaman belajar yang cukup banyak, melalui dari SD, dan MTs oleh karena itu perlu diterapkan pendekatan pembelajaran yang relevan dengan kondisi tersebut, termasuk dalam pembelajaran bahasa Arab. Menurut peneliti pribadi pendekatan yang mampu mengajak peserta didik untuk berfikir kreatif dan mandiri adalah pendekatan konstruktivisme.

Jika pendekatan behaviorisme membuat praktek pembelajaran bahasa Arab lebih banyak meniru guru, maka pendekatan konstruktivesme membuat praktek pembelajaran bahasa Arab dapat membuat peserta didik lebih aktif dan kreatif 


\section{Dzikrul Hakim Al Ghozali, Diki Cahyo Ramadhan.}

dalam proses belajar mengajar, siswa diajak untuk berfikir mandiri, berkreasi dan bereksplorasi, sehingga motivasi dan hasil belajarnya meningkat. Seiring dengan itu, peneliti ingin mengetahui efektifitas penggunaan model pembelajaran maharah kalam berbasis teori konstruktivsme terhadap motivasi belajar siswa Madrasah Aliyah Al-Bairuny Sambongdukuh Jombang.

\section{Pembelajaran Keterampilan Berbicara}

Keterampilan berbicara pada hakikatnya merupakan keterampilan memproduksi arus sistem bunyi artikulasi yang bertujuan untuk menyampaikan kehendak, kebutuhan perasaan, dan keingingan kepada orang lain. Berbicara adalah kemampuan mengucapkan bunyi-bunyi artikulasi atau kata-kata untuk mengekspresikan, menyatakan, atau menyampaikan pikiran, gagasan, dan

perasaan. Berbicara juga merupakan suatu bentuk perilaku manusia yang memanfaatkan faktor-faktor fisik, psikologis, neurologis, semantik, dan linguistik sedemikian ekstensif, secara luas sehingga dapat dianggap sebagai alat manusia yang paling penting bagi kontrol manusia.

\section{a. Model Pembelajaran Al-Kalam}

Diantara model-model latihan percakapan itu ialah sebagai berikut :

1) Tanya jawab

2) Menghafalkan model dialog

3) Percakapan terpimpin

4) Percakapan bebas 


\section{b. Strategi Pembelajaran Al-Kalam}

Strategi pembelajaran keterampilan berbicara antara lain:

1) Strategi Langsung

Strategi ini bertujuan untuk melatih siswa menceritakan apa yang dilihat dalam bahasa Arab baik lisan maupun tulisan. Media yang digunakan dapat berupa gambar baik yang diproyeksikan untuk pembelajaran maupun yang tidak diproyeksiakan.

2) Strategi Group Kecil

Strategi ini sering disebut dengan small group presentation. Dalam strategi ini kelas dibagi menjadi beberapa kelompok akan melakukan tugas yang akan diberikan pengajar, kemudian hasilnya dipresentasikan di kelas. Strategi ini biasanya digunakan untuk lebih mengaktifkan siswa, sehingga masing-masing siswa akan merasakan pengalaman belajar yang sama.

3) Strategi melihat gambar

Strategi ini disebut dengan strategi gallery sessional poster session. Penggunaan strategi ini diantaranya ditujukan untuk melihat kemampuan siswa dalam memahami isi sebuah bacaan kemudian mampu memvisualisasikannya dalam bentuk gambar. Dari gambar tersebut diharapkan semua siswa dapat menghafal isi bacaan secara lebih mudah dan ingatan siswa terhadap isi bacaan tersebut dapat bertahan lama.

\section{Pendekatan Konstruktivisme Dalam Pembelajaran Maharah Kalam}




\section{Dzikrul Hakim Al Ghozali, Diki Cahyo Ramadhan.}

Pendekatan disebut juga dengan teori yaitu dapat dimaknai sebagai titik tolak dalam memandang sesuatu. Dalam konteks pendekatan pembelajaran, rusman mendefinisikan pendekatan sebagai "titik tolak atau sudut pandang terhadap proses pembelajaran". ${ }^{2}$ Secara umum paling tidak ada dua pendekatan dalam pembelajaran, termasuk dalam pembelajaran bahasa Arab, Yaitu : Pertama. Pendekatan pembelajaran yang berpusat pada guru. Kedua, pendekatan pembelajaran yang berpusat pada siswa. Pendekatan pembelajaran yang berpusat pada guru melahirkan beberapa strategi pembelajaran, diantaranya adalah strategi langsung. Sementara pendekatan pembelajaran yangn berpusat pada siswa juga melahirkan sejumlah setrategi pembelajaran, diantaranya strategi pembelajaran tidak langsung.

Menurut Ali Ahmad Madkur, diantara pendekatan/teori belajar mengajar bahasa adalah: teori struktural, teori behaviorisme dan teori kognitifisme. ${ }^{3}$ Menurut Al-Ushaily, salah satu pendekatan yang paling popular dalam pembelajaran bahasa Asing, termasuk pembelajaran bahasa Arab, adalah pendekatan konstruktivisme. Lebih lanjut Al-Ushaily menyatakan : "Diantara pendekatan yang popular dalam pembelajaran bahasa Asing adalah pendekatan sam'iah syafawaiyah (Dengar, ucap), pendekatan natural, pendekatan kognitif, pendekatan komunikatif, pendekatan fungsional, pendekatan konstruktif,

\footnotetext{
${ }^{2}$ Rusman, Model-Model Pembelajaran Mengembangkan Profesionalisme Guru. Cet 5. (Jakarta : PT Raja Grafindo Persada, 2012), 133-134.

${ }^{3}$ Ahli Ahmad Madkur, Thuruq Tadris Al-Lughah Al-Arobiyah, (Amman : Dar Al-Masirah, 2010), Cet. 2, 81
} 
pendekatan kondisional, pendekatan humanis, pendekatan analisis dan non analisis. $^{\prime 4}$

Dengan demikian, konstruktivisme dalam konteks pembelajaran secara umum dan pembelajaran bahasa Arab secara khusus, merupakan sebuah landasan psikologis dan filosofis yang memandang bahwa peserta didik dapat membentuk dan mengembangkan pemahamanya secara mandiri berdasarkan pengalaman dan pengetahuan sebelumnya sesuai dengan rangsangan yang diberikan oleh guru.

Di Indonesia penggunaan pendekatan teori konstruktivisme mulai muncul secara ekspelitis dalam kurikulum 2014. Pendekatan teori konstruktivisme berasumsi bahwa setiap pembelajar mampu belajar mengkonstruk rumusan kebenaran berdasarkan pertimbangan pemikiranya. Pendekatan konstruktivisme digunakan untuk mendasari pemilihan materi, model, dan evaluasi yang sesuai dengan tahap perkembangan kematangan berfikir peserta didik.

Konsep pembelajaran konstruktivisme merupakan pembelajaran yang didasarkan pada pemahaman bahwa proses belajar yang dilakukan peserta didik merupakan proses konstruksi pengetahuan, pemahaman dan pengalaman yang dilakukan oleh peserta didik. Dalam proses pembelajaran ini, pendidik dituntut untuk menjadi fasilitator yang baik, yang mampu menggali potensi yang dimiliki oleh peserta didik.

${ }^{4}$ Abdul Aziz bin Ibrahim Al-Ushaily, Tharaiq Tadris Al-Lughah Al-Arabiyah li Al-Nathiqina bi Lughatin Ukhra, (Riyad : Universitas Islam Imam Muhammad bin Sa’ud, 2002), 21-22. 


\section{Dzikrul Hakim Al Ghozali, Diki Cahyo Ramadhan.}

Ada beberapa metode pembelajaran yang di dalam prosedur pembelajaranya terdapat beberapa karakteristik pembelajaran konstruktivisme. Metode-metode tersebut antara lain :5

a. Strategi Pembelajaran Kooperatif (Cooperatif Learning)

b. Strategi Pembelajaran Berbasis Masalah (Problem Based Learning)

\section{Motivasi Belajar}

Motivasi adalah sesuatu yang dapat membangkitkan gairah dan rasa percaya diri seseorang karna adanya kekuatan dan dorongan untuk melakukan hal yang lebih baik lagi dari sebelumnya. Sikap yang dimiliki oleh setiap orang dengan keinginan untuk mencapai tujuan tertentu meruapakan bentuk dari motivasi.6 Motivasi pada dasarnya muncul karena terstimulasi oleh setiap kebutuhan yang ingin dicapai. Motivasi yang dimiliki oleh peserta didik merupakan keingginan untuk memperoleh penghargaan dalam belajar, sehinga memungkinkan peserta didik untuk terus belajar dengan giat.

Sehingga motivasi belajar siswa adalah dorongan energi pskologis siswa yang melakukan suatu tindakan agar menguasai sesuatu yang baru berupa pengetahuan, keterampilan, kemauan, kebiasaan dan sikap. Apabila siswa memahami tujuan belajar, kemungkinan besar siswa akan termotivasi belajar yang dapat diukur dengan aspek- aspek motivasi belajar siswa. Adapun aspek-aspek

\footnotetext{
${ }^{5}$ Sigit Mangun Wardoyo, Pembelajaran Konstruktivisme : Teori dan Aplikasi Pembelajaran dalam Pembentukan Karakter, (Bandung : Alfabeta, 2015), Cet ke-2, 4

${ }^{6}$ Hamzah B. Uno, Teori Motivasi \& Pengukuranya.(Jakarta : Bumi Aksara, 2008). 21.
} 
motivisi belajar siswa yaitu : menyiapakan diri sebelum mengikuti pelajaran, mengikuti pelajaran di kelas, menidaklanjuti pelajaran disekolah.7

\section{B. METODE PENELITIAN}

Pada penelitian ini, metode penelitian yang penulis gunakan merupakan jenis penelitian kuantitatif. Penarikan data Penelitian Kuantitatif berlandasakan pada pada filsafat positivisme, digunakan untuk meneliti pada populasi atau sampel tertentu. ${ }^{8}$

Pendekatan penelitian ini menggunakan pendekatan penelitian kuantitatif. Dan jenis penelitian ini adalah penelitian quasi eksperimen dengan model One Group pretes-posttest. Metode pengambilan sampel menggunakan teknik Porpusive Sampling. Untuk teknik pengumpulan data digunakan teknik test dan teknik non test. Teknik test menggunakan Pretest-Postest. Teknik non-test menggunakan angket kuesioner. Populasi yang digunakan dalam penelitian ini adalah siswa di Madrasah Aliyah kelas X IPA Al-Bairuny Sambongdukuh Jombang. Tehnik analisa data penelitian dapat dilakukan perhitungan seperti uraian berikut :

1. Hasil belajar siswa

Setelah data terkumpul dari hasil pengumpulan data maka langkah berikutnya adalah mengolah data sesuai dengan pendekatan penelitian,

\footnotetext{
${ }^{7}$ Sadirman, Interaksi dan Motivasi Belajar Mengajar. (Jakarta : PT Raja Grafindo Persada, 2020). 75

${ }^{8}$ Sugiyono, Metode Penelitian Pendidikan Pendekatan Kuantitatif, Kualitatif, dan R\&D, Cet. Ke 22. (Bandung: CV. Alfabeta, 2015), 14.
} 


\section{Dzikrul Hakim Al Ghozali, Diki Cahyo Ramadhan.}

Analisis skor

$$
\underset{N}{\text { Skor }}=\underset{N}{B} \times 100(\text { skala } 0-100)
$$

Keterangan:

$B \quad$ :Skor Soal yang dijawab benar

N : Jumlah skor sempurna/total

Selanjutnya skor hasil tes tersebut dihitung rata-ratanya, serta menghitung nilai gain antara pre-test dan post test. Selanjutnya dilakukan pengolahan data tes awal, tes akhir dan nilai gain dengan menggunakan rumus uji statistik sebagai berikut:

$$
\mathrm{Md}=\frac{\sum d}{n}-
$$

Keterangan:

Md : Mean dari perbedaan pre-test dengan post test

$\sum \mathrm{d} \quad$ : Jumlah Gain (selisih antara pre-test dan post-test)

$\mathrm{N} \quad$ : subjek pada sampel

dihitung menggunakan rumus :

$$
\sum \mathrm{X}^{2} \mathrm{~d}=\sum \mathrm{d}^{2}-\frac{\left(\sum d\right)^{2}}{n}
$$

Keterangan:

$$
\begin{array}{ll}
\sum \mathrm{X}^{2} \mathrm{~d} & \text { : Jumlah Kuadrat deviasi } \\
\sum \mathrm{n} & \text { : Jumlah gain ( selisih antara pre-test dan post-test). } \\
\mathrm{n} & \text { : subjek pada sampel }
\end{array}
$$

Selanjutnya untuk perhitungan uji $\mathrm{t}$ pada taraf signifikan $\mathrm{a}=0,05$ dihitung menggunakan rumus sebagaimana berkut ; 
Efektivitas Penggunaan Model Pembelajaran Maharah Kalam ....

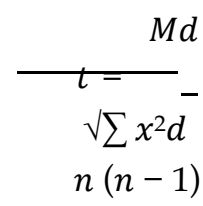

Keterangan:

Md : Mean dari perbedaan pretest dengan posttest

Xd : Deviasi masing-masing subjek (d-Md)

$\sum x^{2} d \quad:$ Jumlah kuadrat deviasi

n : Subjek pada sampel

$\mathrm{Db} \quad$ : derajat bebas (ditentukan dengan N-1) ${ }^{9}$

Hasil $t_{\text {hitung }}$ tersebut kemudian dibandingkan dengan $t$ tabel taraf signifikan $\mathrm{a}=0,05$. Kriteria pengujian hipotesis jika $t_{\text {hitung }} \geq t_{\text {tabel }}$ maka hipotesis tersebut diterima. Hasil thitung tersebut kemudian dibandingkan dengan $t_{\text {tabel }}$ taraf signifikan a $=0,05$. Untuk membandingkan $t_{\text {hitung }}$ dengan $t_{\text {tabel }}$ maka perlu dicari terlebih dahulu derajat kebebasan (d.b) dengan menggunakan rumus :

$$
d \cdot b=(n-1)
$$

ketarangan

d : derajat bebas

b : subjek pada sampel

Kriteria pengujian:

Jika $t_{\text {hitung }} \geq t_{\text {tabel, }}$ maka $\mathrm{H}_{0}$ diterima.

Jika $t_{\text {hitung }}<t_{\text {tabel, }}$ maka $\mathrm{H}_{1}$ ditolak.

${ }^{9}$ Sukardi, Metedologi pendidikan Kompetensi dan Praktiknya, (Jakarta:Bumi Aksara,2004), h.86 


\section{Dzikrul Hakim Al Ghozali, Diki Cahyo Ramadhan.}

2. Motivasi Belajar Siswa

Untuk mengetahui nilai prersentase dari hasil angket motivasi siswa terdiri dari 6 soal. Metode yang digunakan terdiri dari 5 Level skala likert yaitu : sangat setuju (SS), Setuju(S), kurang Setuju (KS), tidak setuju (TS), dan sangat tidak setuju (STS). Dianalisis dengan menggunakan rumus sebagai berikut:

$$
\mathrm{P}=\underset{F}{100 x-N}
$$

Keterangan:

$\mathbf{P} \quad$ : Nilai presentase jawaban responden

F : jumlah semua jawaban responden

N : jawaban responden

100 : bilangan konstanta (tetap)

Dengan Kriteria:

\begin{tabular}{|l|l|}
\hline $76-100 \%$ & $=$ Sangat tinggi \\
\hline $51-75 \%$ & $=$ Tinggi \\
\hline $25-50 \%$ & $=$ rendah \\
\hline $0-25 \%$ & $=$ Sangat rendah ${ }^{10}$ \\
\hline
\end{tabular}

\section{HASIL DAN PEMBAHASAN}

\section{Hasil Belajar Siswa}

Pada langkah ini digunakan untuk menguraikan data yang telah diperoleh dari penyebaran angket kepada 87 responden ke dalam tabel mean (rata-rata), sehingga dalam tabel tersebut akan dipoeroleh hasil dari variabel $X$ (Kecerdasan Spiritual) dan Variabel Y (Kedisiplinan Santri dalam menjalankan Peraturan).

\footnotetext{
${ }^{10}$ Anas Sudjono, Pengantar Statistik pendidikan, ( jakarta: Raja Grafindo Persada, 2008), h.43
} 
Efektivitas Penggunaan Model Pembelajaran Maharah Kalam ....

Implementasi teori konstruktivisme dalam keterampilan berbicara menigkatkan hasil belajar siswa. Hal ini dibuktikan dengan analisis data yang menunjukkan tes awal yang masih berbasis konvensional dengan diberikan pretest dan tes akhir yang berbasis teori konstruktivisme dengan diberikan posttest memiliki perbedaan hasil. Dimana hasil tes akhir nilai rata-rata posttest lebih meningkat dari pada nilai rata pretest. Dengan nilai rata-rata yang dapat dilihat pada tabel berikut ini:

Tabel 1. Rata-Rata Nilai Pretest dan Rata-Rata Nilai Posttets dan Gain

\begin{tabular}{|c|c|c|c|c|c|}
\hline No & $\begin{array}{l}\text { Kode } \\
\text { Siswa }\end{array}$ & $\begin{array}{l}\text { Pre- } \\
\text { test }\end{array}$ & $\begin{array}{c}\text { Post- } \\
\text { test }\end{array}$ & Gain (d) & $\mathrm{d}^{2}$ \\
\hline (1) & (2) & (3) & (4) & (5) & (6) \\
\hline 1 & $\mathrm{X} 1$ & 65 & 70 & 5 & 25 \\
\hline 2 & $\mathrm{X} 2$ & 50 & 70 & 20 & 400 \\
\hline 3 & $\mathrm{X} 3$ & 60 & 75 & 15 & 225 \\
\hline 4 & $\mathrm{X} 4$ & 55 & 70 & 15 & 225 \\
\hline 5 & X5 & 65 & 85 & 20 & 400 \\
\hline 6 & $\mathrm{X} 6$ & 50 & 65 & 15 & 225 \\
\hline 7 & X7 & 60 & 70 & 10 & 100 \\
\hline 8 & $\mathrm{X} 8$ & 65 & 80 & 15 & 225 \\
\hline 9 & X9 & 55 & 70 & 15 & 225 \\
\hline 10 & X10 & 35 & 60 & 25 & 625 \\
\hline 11 & X11 & 60 & 70 & 10 & 100 \\
\hline 12 & $\mathrm{X} 12$ & 55 & 65 & 10 & 100 \\
\hline 13 & $\mathrm{X} 13$ & 65 & 75 & 10 & 100 \\
\hline 14 & X14 & 55 & 70 & 15 & 225 \\
\hline 15 & X15 & 60 & 65 & 10 & 100 \\
\hline 16 & X16 & 65 & 75 & 10 & 100 \\
\hline 17 & $\mathrm{X} 17$ & 50 & 75 & 25 & 625 \\
\hline 18 & X18 & 60 & 75 & 15 & 225 \\
\hline 19 & X19 & 65 & 70 & 5 & 25 \\
\hline 20 & $X 20$ & 55 & 70 & 15 & 225 \\
\hline 21 & $\mathrm{X} 21$ & 60 & 80 & 20 & 400 \\
\hline 22 & $\mathrm{X} 22$ & 60 & 70 & 10 & 100 \\
\hline 23 & $\mathrm{X} 23$ & 55 & 70 & 15 & 225 \\
\hline
\end{tabular}




\section{Dzikrul Hakim Al Ghozali, Diki Cahyo Ramadhan.}

\begin{tabular}{|c|l|l|l|l|l|}
\hline $\mathbf{2 4}$ & $\mathrm{X} 24$ & 60 & 80 & $\mathbf{2 0}$ & $\mathbf{4 0 0}$ \\
\hline $\mathbf{2 5}$ & $\mathrm{X} 25$ & 65 & 85 & 20 & $\mathbf{4 0 0}$ \\
\hline $\mathbf{2 6}$ & $\mathrm{X} 26$ & 55 & 75 & 20 & $\mathbf{4 0 0}$ \\
\hline $\mathbf{2 7}$ & $\mathrm{X} 27$ & 60 & 80 & 20 & $\mathbf{4 0 0}$ \\
\hline $\mathbf{2 8}$ & $\mathrm{X} 28$ & 60 & 85 & 25 & $\mathbf{6 2 5}$ \\
\hline $\mathbf{2 9}$ & $\mathrm{X} 29$ & 65 & 80 & 15 & $\mathbf{2 2 5}$ \\
\hline $\mathbf{3 0}$ & $\mathrm{X} 30$ & 30 & 65 & 35 & $\mathbf{1 2 2 5}$ \\
\hline \multirow{2}{*}{ JumlahTotal } & & 1720 & 2195 & 480 & $\mathbf{8 9 0 0}$ \\
\hline Rata-rata & & $\mathbf{5 7 , 3 3}$ & $\mathbf{7 3 , 1 6}$ & $\mathbf{1 6}$ & $\mathbf{2 9 6 , 6 6}$ \\
\hline
\end{tabular}

Pada tabel diatas terlihat nilai postest yang pembelajarannya menggunakan teori konstruktivisme lebih dominan dibandingkan dengan nilai pretest yang masih menggunakan pembelajaran konvensional. Hal ini dibuktikan dengan perbedaan perolehan nilai rata- rata pre-test sebanyak 57,33\%, sedangkan nilai rata-rata posttest sebanyak 73,16\% dengan rata-rata selisih gain 16. Jika diperhatikan dari hasil pretest, nilai yang diperoleholeh peserta didik tidak mampu mencapai nilai KKM (Kriteria Ketuntasan Minimal), nilai KKM yang ditentukan adalah 70. Perolehan nilai yang paling tinggi dari hasil pretest adalah 65 sedangkan untuk perolehan nilai paling rendah adalah 35. Namun berdasarkan nilai dari hasil post-test, sebanyak 25 peserta didik mampu mencapai nilai KKM yang telah ditentukan dengan perolehan nilai paling tinggi adalah 85 dan perolehan nilai paling rendah adalah 60. Adapun nilai rata-rata pretest dan posttest dan selisih gain dapat dilihat pada gambar grafik berikut; 


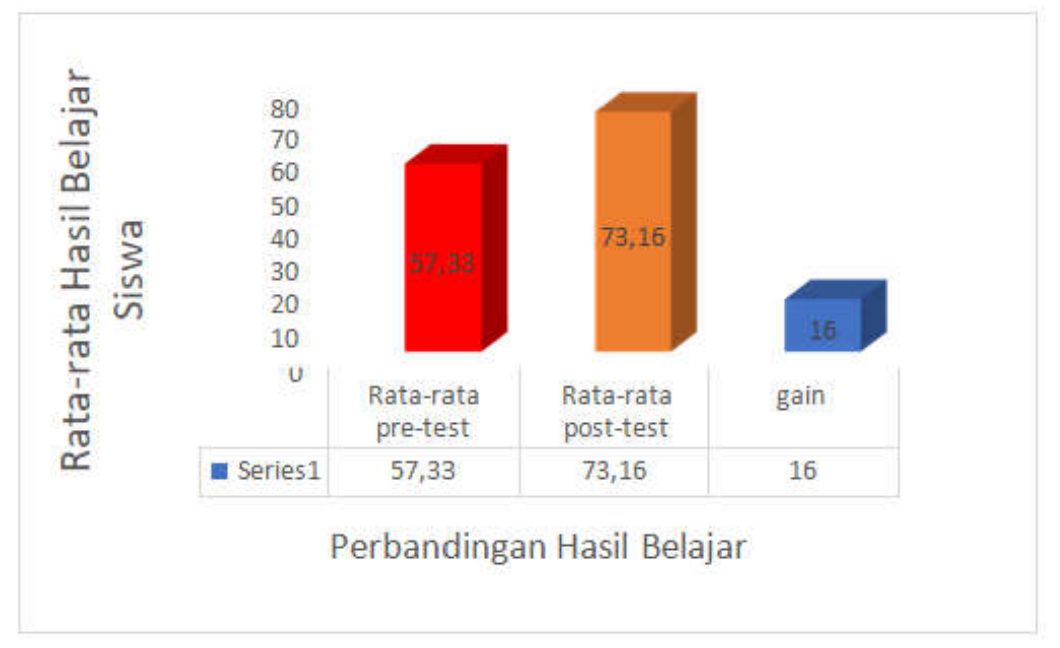

Gambar 1. Grafik Perbandingan Hasil Belajar

Pada gambar grafik diatas memperlihatkan bahwa peserta didik dengan mengunakan teori kontruktivisme dapat meningkatkan hasil belajar siswa dan mampu lebih memahami materi. Setelah mendapat nilai rata-rata pretest dan nilai rata-rata postest dengan selisih nilai gain 16 maka data dianalis menggunakan rumus uji t dengan taraf signifikan $5 \%(0,05)$.

Selanjutnya hasil $t_{\text {hitung }}$ tersebut kemudian dibandingkan dengan $t_{\text {tabel }}$ taraf signifikan $a=0,05$. Kriteria pengujian hipotesis jika $t_{\text {hitung }} \geq t_{\text {tabel }}$ maka hipotesis tersebut diterima. Hasil thitung tersebut kemudian dibandingkan dengan $t_{\text {tabel }}$ taraf signifikan a $=0,05$. Untuk membandingkan $t_{\text {hitung }}$ dengan $t_{\text {tabel }}$ maka perlu dicari terlebih dahuluderajat kebebasan (d.b) dengan menggunakan rumus :

$$
\text { d.b }=(n-1)
$$




\section{Dzikrul Hakim Al Ghozali, Diki Cahyo Ramadhan.}

Hasil Analisis data yang diperoleh dari perhitungan rumus di atas memperlihatkan nilai rata-rata pretest dan nilai rata-rata posttest dengan selisih nilai gain 16. Mendapatkan hasil $t_{\text {hitung }} 11,42$ dan untuk nilai $t_{\text {tabel }} 1,70$ pada tarafsignifikan 0,05 dengan derat bebas 29 (untuk analaisis data dapat dilihat pada lampiran). Hal ini membuktikan dengan perolehan $t_{\text {hitung }}>t_{\text {tabel }}$ sehingga dapat disimpulkan bahwa $\mathrm{H}_{1}$ ditolak dan $\mathrm{H}_{0}$ diterima. Dengan ini hasil penelitian mempelihatkan yaitu Penerapan Model Pembelajaran Keterampilan berbicara berbasis teori konstruktivisme dapat meningkatkan hasil belajar siswa di Madrasah Aliyah kelas X IPA Al-Bairuny Sambongdukuh Jombang.

\section{Motivasi Belajar Siswa}

Dari semua pertanyaan angket kuesioner motivasi belajar siswa. Peneliti merangkum semua jawaban responden. Berdasarkan indikator Motivasi yaitu keinginan untuk berhasil, keinginan untuk belajar, dorongan yang kuat dalam belajar, keinginan akan cita-cita yang lebih baik, dan keinginan untuk memperoleh penghargaan dalam belajar. Diketahui bahwa motivasi belajar siswa yang diajarkan dengan model pembelajaran keterampilan berbicara berbasis teori konstruktivisme termasuk kategori tinggi dengan jumlah keseluruhannya. Dapat dilihat pada tabel berikut ini.

Tabel 2. Jawaban Responden Dari Semua Pernyataan

\begin{tabular}{|c|l|l|l|l|l|l|l|l|}
\hline No & Indikator & Pernyataan & SS & S & KS & TS & STS & $\begin{array}{c}\text { Rata- } \\
\text { Rata }\end{array}$ \\
\hline$(1)$ & \multicolumn{1}{|c|}{$(2)$} & $(3)$ & $(4)$ & $(5)$ & $(6)$ & \multicolumn{1}{|c|}{$(7)$} & \multicolumn{1}{|c|}{$(8)$} & $(9)$ \\
\hline 1 & $\begin{array}{l}\text { Hasrat dan } \\
\text { keinginan } \\
\text { berhasil }\end{array}$ & $\begin{array}{l}\text { Saya lebih } \\
\text { memahami materi } \\
\text { yang telah }\end{array}$ & 40 & 60 & 0 & 0 & 0 & 100 \\
\hline
\end{tabular}




\begin{tabular}{|c|c|c|c|c|c|c|c|c|}
\hline & & $\begin{array}{l}\text { diajarkan guru } \\
\text { dengan } \\
\text { menggunakan } \\
\text { model } \\
\text { pembelajaran } \\
\text { keterampilan } \\
\text { berbicara berbasis } \\
\text { teori } \\
\text { konstruktivisme. }\end{array}$ & & & & & & \\
\hline & & $\begin{array}{l}\text { Dengan } \\
\text { menggunakan } \\
\text { model } \\
\text { pembelajaran } \\
\text { keterampilan } \\
\text { berbicara } \\
\text { berbasis teori } \\
\text { konstruktivisme } \\
\text { dapat } \\
\text { meningkatkan } \\
\text { hasil belajar saya }\end{array}$ & 63,33 & 33.33 & 33,33 & 0 & 0 & 100 \\
\hline & & $\begin{array}{l}\text { Saya berminat } \\
\text { untuk mengikuti } \\
\text { pembelajaran } \\
\text { selanjutnya } \\
\text { dengan } \\
\text { menggunakan } \\
\text { model } \\
\text { pembelajaran } \\
\text { keterampilan } \\
\text { berbicara } \\
\text { berbasis teori } \\
\text { konstruktivisme. }\end{array}$ & 23,63 & 66,67 & 10 & 0 & 0 & 100 \\
\hline \multirow[t]{2}{*}{2} & $\begin{array}{l}\text { Dorongan } \\
\text { dan } \\
\text { kebutuhan } \\
\text { dalam } \\
\text { belajar }\end{array}$ & $\begin{array}{l}\text { Saya merasa } \\
\text { senang belajar di } \\
\text { kelas atau } \\
\text { dirumahdengan } \\
\text { menggunakan } \\
\text { model } \\
\text { pembelajaran } \\
\text { keterampilan } \\
\text { berbicara } \\
\text { berbasis teori } \\
\text { konstruktivisme. }\end{array}$ & 30 & 66,67 & 3,33 & 0 & 0 & 100 \\
\hline & & $\begin{array}{l}\text { Saya merasa lebih } \\
\text { bersemangat } \\
\text { belajar di kelas } \\
\text { atau dirumah } \\
\text { dengan } \\
\text { mengunakan } \\
\text { model }\end{array}$ & 36,67 & 60 & 3,33 & 0 & 0 & 100 \\
\hline
\end{tabular}




\section{Dzikrul Hakim Al Ghozali, Diki Cahyo Ramadhan.}

\begin{tabular}{|c|c|c|c|c|c|c|c|c|}
\hline & & $\begin{array}{l}\text { pembelajaran } \\
\text { keterampilan } \\
\text { berbicara } \\
\text { berbasis teori } \\
\text { konstruktivisme. }\end{array}$ & & & & & & \\
\hline \multirow[t]{2}{*}{3} & $\begin{array}{l}\text { Harapan } \\
\text { dan cita-cita } \\
\text { di masa } \\
\text { depan }\end{array}$ & $\begin{array}{l}\text { Dengan } \\
\text { menerapkan } \\
\text { model } \\
\text { pembelajaran } \\
\text { keterampilan } \\
\text { berbicara } \\
\text { berbasis teori } \\
\text { konstruktivisme } \\
\text { dapat } \\
\text { meningkatkan } \\
\text { kemandrian saya } \\
\text { dalam } \\
\text { menyelesaikan } \\
\text { tugas yang } \\
\text { diberikan guru. }\end{array}$ & 40 & 60 & 0 & 0 & 0 & 100 \\
\hline & & $\begin{array}{l}\text { Tujuan saya } \\
\text { mempelajari } \\
\text { materi } \\
\text { keterampilan } \\
\text { berbicara tidak } \\
\text { hanya untuk } \\
\text { mendapatkan } \\
\text { nilai yang baik, } \\
\text { tetapi juga untuk } \\
\text { pengetahuan } \\
\text { saya. }\end{array}$ & 43,33 & 46,67 & 10 & 0 & 0 & 100 \\
\hline 4 & $\begin{array}{l}\text { Pengharga } \\
\text { an dalam } \\
\text { belajar }\end{array}$ & $\begin{array}{l}\text { Saya merasa } \\
\text { senagapabila } \\
\text { guru memuji } \\
\text { keberhasilan saya } \\
\text { dalam enjawab } \\
\text { pertanyaan- } \\
\text { pertanyaan atau } \\
\text { mendapatkan } \\
\text { nilaiyang bagus }\end{array}$ & 56,67 & 43,33 & 0 & 0 & 0 & 100 \\
\hline 5 & $\begin{array}{l}\text { Kegiatan } \\
\text { yang } \\
\text { menarik } \\
\text { dalam } \\
\text { belajar }\end{array}$ & $\begin{array}{l}\text { Dengan } \\
\text { menggunakan } \\
\text { model } \\
\text { pembelajaran } \\
\text { keterampilan } \\
\text { berbicara berbasis } \\
\text { teori } \\
\text { konstruktivisme } \\
\text { yang sayaikuti } \\
\text { jadi lebih mudah }\end{array}$ & 53,33 & 46,67 & 0 & 0 & 0 & 100 \\
\hline
\end{tabular}




\begin{tabular}{|c|c|c|c|c|c|c|c|c|}
\hline & & di pahami. & & & & & & \\
\hline & & $\begin{array}{l}\text { Model } \\
\text { pembelajaran } \\
\text { keterampilan } \\
\text { berbicara berbasis } \\
\text { teori } \\
\text { konstruktivisme } \\
\text { dapat } \\
\text { menghilangkan } \\
\text { rasa bosan saya } \\
\text { saat belajar. }\end{array}$ & 33,33 & 66,67 & 0 & 0 & 0 & 100 \\
\hline & & $\begin{array}{l}\text { Saya lebih mudah } \\
\text { mengingat materi } \\
\text { ketika belajar } \\
\text { dengan } \\
\text { menggunakan } \\
\text { model } \\
\text { pembelajaran } \\
\text { keterampilan } \\
\text { berbicara berbasis } \\
\text { teori } \\
\text { konstruktivisme }\end{array}$ & 53,33 & 46,67 & 0 & 0 & 0 & 100 \\
\hline \multirow[t]{2}{*}{6} & $\begin{array}{l}\text { Lingkungan } \\
\text { Yang } \\
\text { Kondusif }\end{array}$ & $\begin{array}{l}\text { Dengan } \\
\text { menggunakan } \\
\text { model } \\
\text { pembelajaran } \\
\text { keterampilan } \\
\text { berbicara berbasis } \\
\text { teori } \\
\text { konstruktivisme } \\
\text { dapat } \\
\text { menumbuhkan } \\
\text { keberanian saya } \\
\text { dalam } \\
\text { menyampaikan } \\
\text { pendapat dan } \\
\text { berinteraksi } \\
\text { denganguru } \\
\end{array}$ & 46,67 & 50 & 3,33 & 0 & 0 & 100 \\
\hline & & JUMLAH & 43,33 & 53,89 & 2,78 & 0,0 & 0,0 & 100 \\
\hline
\end{tabular}

Pada tabel diatas terlihat bahwa dari semua pernyataan responden yang menjwab sangat setuju sebesar $43,33 \%$ responden dan yang menjawab setuju sebesar 53,89\% responden sedangkan yang menjawab kurang setuju sebesar 2,78\% responden. Jika diperhatikan bahwa dapat disimpulkan Implementasi teori 


\section{Dzikrul Hakim Al Ghozali, Diki Cahyo Ramadhan.}

konstruktivisme dalam proses pembelajaran keterampilan berbicara mampu untuk memotivasi belajar siswa dengan kategori tinggi yaitu sebesar 53,89\% yang menjawab setuju.

\section{KESIMPULAN}

Berdasarkan hasil penelitian yang telah dilaksanakan tentang efektivitas pembelajaran maharah kalam berbasis teori konstruktivesme dalam meningkatkan motivasi belajar siswa, maka diperoleh kesimpulan sebagai berikut:

1. Berdasarkan dari hasil implementasi model pembelajaran keterampilan berbicara berbasis teori konstruktivisme siswa di Madrasah Aliyah kelas X IPA Al-Bairuny Sambongdukuh Jombang sebagai model pembelajaran yang baru untuk memahami materi keterampilan berbicara mendapatkan hasil Belajar yang meningkat dengan memperlihatkan nilai rata-rata pre-test sebanyak $57,33 \%$, sedangkan nilai rata-rata post-test sebanyak $73,16 \%$ dengan selisih nilai gain 16. Hal ini membuktikan dengan perolehan $t_{\text {hitung }}>t_{\text {tabel. }}$ sehingga merperlihatkan bahwa $\mathrm{H}_{1}$ ditolak dan $\mathrm{H}_{0}$ diterima, oleh karena itu dapat disimpulkan model pembelajaran keterampilan berbicara berbasis teori konstruktivisme efektif dan mampu meningkatkan hasil belajar siswa.

2. Berdasarkan penyebaran angket/kuesioner yang diberikan kepada siswa setelah mengikuti pembelajaran keterampilan berbicara berbasis teori konstruktivisme untuk mencari motivasi belajar, menunjukkan bahwa siswa 
Efektivitas Penggunaan Model Pembelajaran Maharah Kalam ....

termotivasi. Dengan hasil yang memperlihatkan Implementasi model pembelajaran keterampilan berbicara berbasis teori konstruktivisme mampu untuk memotivasi belajar siswa dengan kategori tinggi yaitu sebesar 53,89\% yang menjawab setuju.

\section{E. DAFTAR PUSTAKA}

Al-Gholayin, Mustofa. "Jami' Ad-Durus Al-Abiyah". Jilid 1. BAirut : Dar AlKutub Al-Ilmiyah, 2005.

Aziz, Abdul Bin Ibrahim Al-Ushaily. "Tharoiq Tadris Al-Lughah Al-Arobiyah li Al-Nathiqina bi Lughotin Ukhra. Riyad : Universitas Islam Imam Muhammad bin Sa'ud, 2002.

Hadi, Sutrisno. Penelitian Research. Yogyakarta : BPFE, 2004.

Hermawan, Acep. "Metodologi Pembelajaran Bahasa Arab". Bandung Rosdakarya, 2011.

Mustofa, Syaiuful. "Strategi Pembelajaran : Bahasa Arab Inovativ". Malang : UIN Maliki Press, 2011.

Madkur, Ahli Ahmad. "Thuruq Tadris Al-Lughah Al-Arobiyah". Amman : Dar Al-masirah, 2010.

Rosyidi, Abd wahab dan Mamlu'atul Ni'mah. "Memahami Konsep Dasar Pembelajaran Bahasa Arab". Malang : UIN Maliki Press, 2012.

Rusman. "Model-Model Pembelajaran Mengembangkan Profesionalisme Guru". Cet ke-5. Jakarta : PT Raja Grafindo Persada, 2012.

Sani, Ridwan Abdullah. "Inovasi Pembelajaran". Cet ke-1. Jakarta : Bumi Aksara, 2013.

Sadirman, "Interaksi dan Motivasi Belajar Mengajar". Jakarta : PT Raja Grafindo Persada, 2020. 


\section{Dzikrul Hakim Al Ghozali, Diki Cahyo Ramadhan.}

Susilo, Sutarjo Adi. "Pembelajaran Nilai Karakter : Konstruktivisme dan VCT Sebagai Inovasi Pendekatan Pembelajaran Efektif". Jakarta : PT Raja Grafindo Persada, 2012.

Tanzeh, Ahmad. "Pengantar Metode Penelitian". Yogyakarta : Teras, 2009.

Uno, Hamzah B. “Teori Motivasi \& Pengukuranya”. Jakarta : Bumi Aksara, 2008.

Wahyu. Hasil wawancara dengan guru Bahasa Arab Madrasah Aliyah AlBairuny pada tanggal 24 Maret 2021 pukul 10.15 WIB.

Wardoyo, Sigit Mangun. "Pembelajaran Konstruktivisme : Teori dan Aplikasi Pembelajaran Dalam Pembentukan Karakter". Cet ke-2. Bandung : Alfabeta, 2015. 